\title{
Climate Change Impact on Water Resources; The Case of Tono Irrigation Dam in Ghana
}

\author{
Edward Naabil1, *, Benjamin Lantei Lamptey², Kouakou Kouadio ${ }^{3}$, Thompson Annor ${ }^{4}$ \\ ${ }^{1}$ Department of Agricultural Engineering, Bolgatanga Technical University, Bolgatanga, Ghana \\ ${ }^{2}$ School of Earth and Environment, University of Leeds, Leeds, UK \\ ${ }^{3}$ Laboratoire de Physique de, University Félix Houphouet-Boigny, Abidjan, Côte d'Ivoire \\ ${ }^{4}$ Department of Physics, Kwame Nkrumah University of Science and Technology (KNUST), Kumasi, Ghana
}

Email address:

naabil.edward@bpoly.edu.gh (E. Naabil)

${ }^{*}$ Corresponding author

\section{To cite this article:}

Edward Naabil, Benjamin Lantei Lamptey, Kouakou Kouadio, Thompson Annor. Climate Change Impact on Water Resources; The Case of Tono Irrigation Dam in Ghana. Hydrology. Vol. 8, No. 4, 2020, pp. 69-78. doi: 10.11648/j.hyd.20200804.12

Received: October 25 2020; Accepted: November 5, 2020; Published: November 30, 2020

\begin{abstract}
West Africa (WA) in recent past experienced decreasing rainfall and increasing temperature. A preliminary assessment of these trends in the future (2025-2045) was conducted to evaluate its potential impact on water resources, specifically the Tono irrigation dam in Ghana. The climate change assessment was based on future climate data of Representative Concentration Pathways (RCPs) 4.5 and 8.5 projected with ECHAM6 model and downscaled by the Weather Research and Forecasting (WRF) model in reference with historical data (1990-2010). A 2-domain configuration was used: an outer domain at $25 \mathrm{~km}$ horizontal resolution encompassing the West African Region and an inner domain at $5 \mathrm{~km}$ horizontal resolution centered on the Tono basin. The assessment was done based on the annual mean, relative percentage change and spatial seasonal change of the simulated precipitation and temperature. The results show that for precipitation, both scenarios do not agree on the signal of change. RCP4.5 indicates an increase (+7\%) in annual precipitation amount whereas RCP 8.5 indicates a decrease (-9.6\%). For temperature, both scenarios agree on increasing temperature. These results shows that future streamflow will be influenced by climate change. The indications are that the flows will reduce does the dam levels will also reduce does affecting irrigation activities. This studies therefore provides information to the managers of Tono irrigation dam what measures to put in place for its sustainability.
\end{abstract}

Keywords: RCPs, Climate Change, Streamflow, WRF Model, Water Resources, Sustainability

\section{Introduction}

Water resources are key to the survival of society and ecosystems. The health and survival of man depends on water. It is also for agricultural production, transport (navigation), power generation, recreation, and industrial activities. These activities places pressure on water resources leading to water stress and this is likely to be exacerbated by climate change. Water resources (such as dams, rivers, streams, lakes) are major economic and natural resources that West Africa (WA) is endowed with. However, recent studies have indicated that these resources are increasingly under threat. The quality of water is increasingly decreasing with unequal distribution with respect to space and time $[1,2]$. The threat to water resources have been attributed to the impact of climate change. Climate change is likely to increase water demand whiles reducing supplies in many regions. The shift in balance would drive water resource managers to examine how to meet the needs of growing communities, sensitive ecosystems, farmers, energy producers and industry. Climate change is mainly influenced by anthropogenic activities resulting in an increase in greenhouse gases in the atmosphere and therefore contributes significantly to the water balance $[3,2]$. The decline in water resources availability due to decreasing rainfall amounts and increasing temperature across WA, has been attributed to the impact of climate change [4-9]. In some areas water shortage is not much of an issue as the case of increases in runoff and flooding. These effects can destroy the infrastructure (e.g. Dam wall, spillway, 
canals) that is used to transport and deliver water.

Higher temperatures increases the rate of evaporation of water into the atmosphere, thus increasing the atmosphere's capacity to "hold" water [10]. Increased evaporation may result in some areas drying out and fall as excess precipitation on other areas. Changes in the amount of rainfall as a result of increases in evaporation during storms is an evidence that the hydrological cycle is already altering. Once the hydrological cycle is being altered, it makes it difficult to rely on historical data to predict the future hydrological pattern. Dams that were designed and constructed in time past were designed with respect to the climate of that time and therefore in our present time, these dams will not be able to withstand rapid shifts in river flows and precipitation. Therefore failure to adequately predict the future impact of climate change on water resources will make it difficult to adequately manage these resources. Droughts and floods are amongst the most significant natural hazards influenced by climate change that potentially could negatively impact dams' sustainability.

In order that water resources managers and policy makers could better manage these resources in climate change context, it is imperative to understand the future climate change impact on these resources. This will require projection of the changes in the future climate and how these changes will impact water resources. Studies of this nature will provide an insight as to the likely events and what steps to put in place in other to sustain these resources. A number of studies have been carried out with respect to the climate and hydrological dynamics of some river basins particularly for the purposes of assessment and management of these resources across WA $[1,11]$. The studies done by Ardoin et al., 2015 and Rescan, 2005; showed that the runoff and water availability of the Sassandra River in Cote d'Ivoire, would increase from $10-13 \%$ during the first half of the $21^{\text {st }}$ century (Horizon, 2050) $[12,13]$. Most of these studies simulated the climate from HadCM3 global climate model with A2 greenhouse gas emission scenario. Recent studies by Coulibaly et al., 2018, Yao, 2015, Abiodun et al., 2013, Sylla et al., 2010, Barthony et al., 2010, Mariotti et al, 2010, used the
Regional Climate Model (RegCM3) under the A1B emission scenario to evaluate the impact of climate change over WA [2, 14-18]. The Special Report on Emission Scenarios (SRES), was applied in many of these studies, however, these scenarios are no longer in use. Applying the relatively updated IPCC future scenarios (i.e. Representative Concentration Pathways), provides an improved means of assessing the impact of the climate change on water resources. Additional information may be obtained as well given the advantages of the RCPs over the SRES scenarios.

This study which is particularly focused on the Tono dam in Ghana, WA, relied on simulation of future climate data generated from a state of the art regional climate model, Advanced Weather Research and Forecasting (WRF) model, version 3.5, under the Representative Concentration Pathways (RCP) 4.5 and 8.5. The data generated was used to evaluate climate change at the Tono dam and its consequent impact on the sustainability of the irrigation scheme.

\section{Data and Methods}

\subsection{Study Area}

The Tono dam, located at latitude $10^{\circ} 52^{\prime} \mathrm{N}$, longitudes $1^{\circ}$ $08^{\prime}$ W, in the Kassena Nakana Municipality of the Upper East Region of Ghana, is one of the largest irrigation dams in West Africa. The main rivers draining into the basin are Gaabuga and Songobuga (Figure 1). These rivers take their source from the southern part of Burkina Faso. The Tono dam drains a catchment area of $650 \mathrm{~km}^{2}$. Its surface area is $18.6 \mathrm{~km}^{2}$, with a length of $4 \mathrm{~km}$ and a crest height of $18.6 \mathrm{~m}$. The topography of the Tono basin is one of gentle slope and a flat terrain and the basin altitude is $160 \mathrm{~m}$. The climate of the area is made up of two distinct seasons; a dry season (November-April) and a rainy season (May-September), with an annual mean rainfall of about $950 \mathrm{~mm}$. The peak rainfall usually occurs in August and the mean monthly temperature varies between $26.5^{\circ} \mathrm{C}$ and $33^{\circ} \mathrm{C}$.

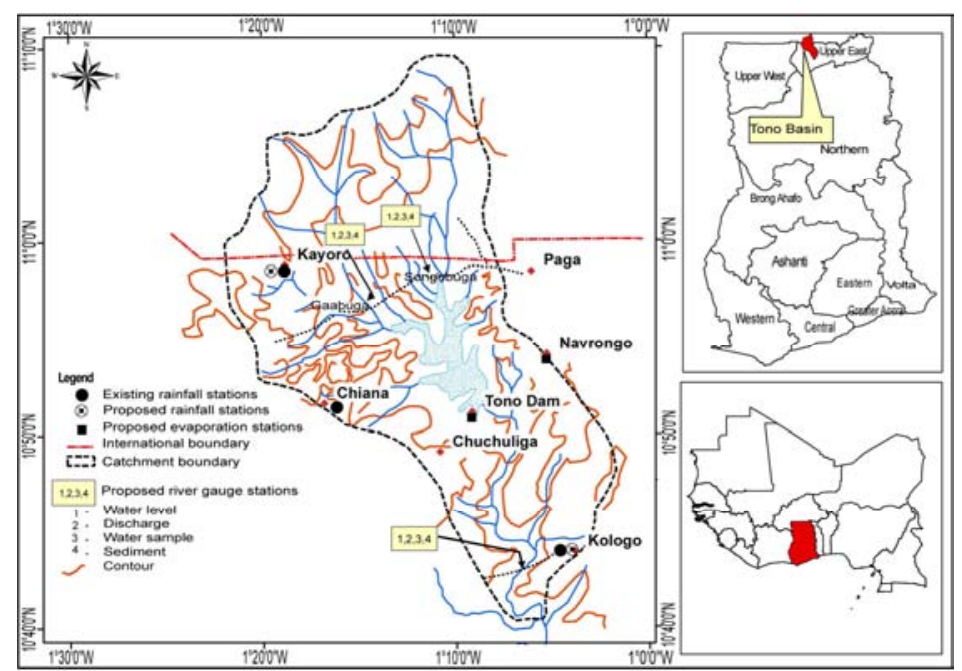

Figure 1. Map of Tono drainage Basin in the Kassena Municipality (left figure), project site (top right figure) and the location of Ghana in West Africa (bottom right figure). 

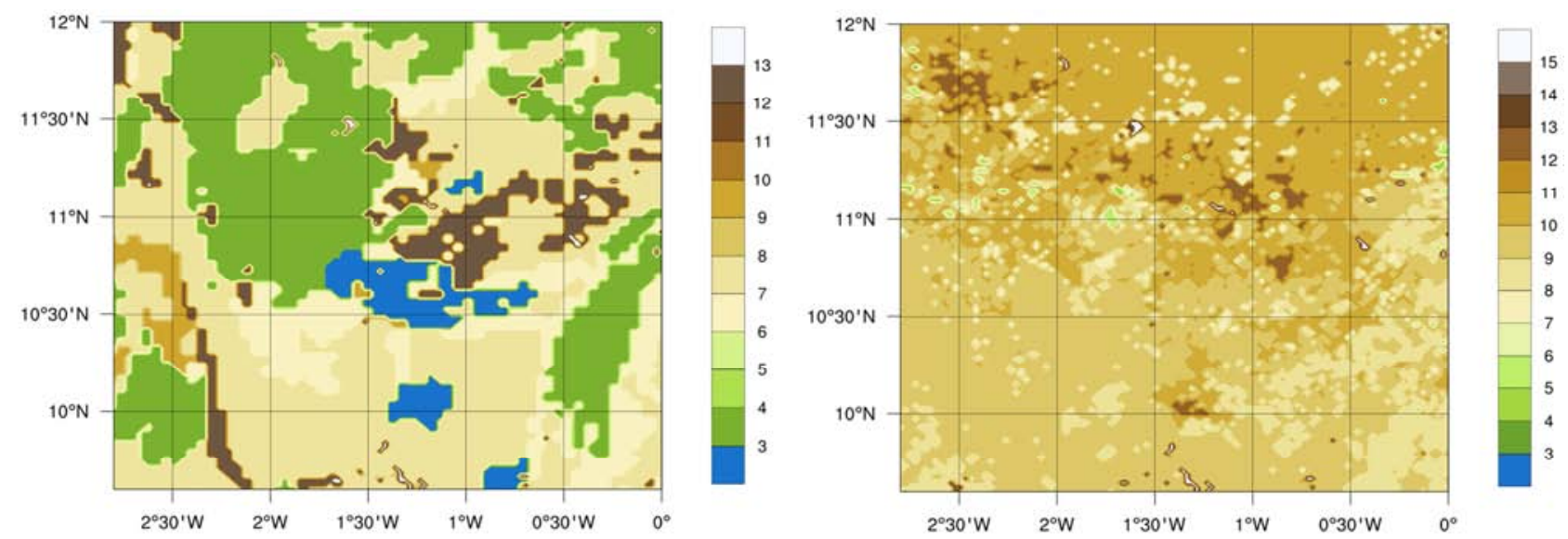

Figure 2. Dominant soil category (a) at the Tono basin (Blue $=$ Water, $3=$ Sandy loam, $4=$ Silt loam, 5=Silt, $6=$ loam, $7=$ Sandy clay loam, $8=$ Silty clay loam, $9=$ clay loam, 10=Sandy clay, 11=Silty clay, 12=Clay, 13=Organic material) and (b) Dominant vegetation cover at the Tono basin based on MODIS Land use categories $(8=$ Woody savanna, $9=$ Savannas, $10=$ Grasslands, $11=$ Permanent Wetlands, $12=$ Croplands, $13=U r b a n$ and Built - Up $)$.

The basin's vegetation covers are: Woody savanna, Savannas, Grasslands, Permanent wetlands (irrigated fields) and Croplands and it's soil category is sandy loam, interspersed with other soil types (e.g. Loam, Sandy clay loam, Sandy clay, Silty clay and Clay) [see Figure 2]. The rate of infiltration and surface runoff generation at the catchment is influenced mainly by the soil type and the vegetation cover.

The Tono irrigation dam was constructed in 1975 and was handed over to the Irrigation Company of Upper Region (ICOUR) for management in 1980. The primary objective of the irrigation scheme is to provide at least eight communities within the catchment area, the opportunity of dry season farming. This will ensure food security and economic livelihood.

ICOUR over the years has observed a reduction in the irrigable area of the catchment and this has been attributed to the decreasing water level of the dam.

\subsection{Data}

The monthly observed (gridded) climate data (rainfall and temperature) from 1990 to 2010 used in this study was provided by The Tropical Rainfall Measuring Mission (TRMM), [19] and Climate Research Unit (CRU) data set for Africa version TS3.0 [20] for temperature, comparisons. TRMM provides precipitation at a daily time scale. CRU temperature was interpolated from $50 \mathrm{~km}$ resolution to a 5 $\mathrm{km}$ grid, using the Nearest Neighbour interpolation (NNI) originally developed by Sibson, 1981 [21]. This is a baseline method that has been used for many years [22] as a standard part of the library of graphics functions provided by the National Center for Atmospheric Research (NCAR), (ngwww.ucar.edu/documentation.html). The interpolation from $50 \mathrm{~km}$ to $5 \mathrm{~km}$ is to enable comparison with the Regional Climate Model (RCM) output at the same grid resolution to evaluate the performance of the model. These data sets were initially validated with available ground truth data, which showed good agreement. Though CRU has precipitation data, TRMM precipitation was used because it showed a better agreement with ground truth data. The data sets (TRMM and CRU) were used due to inadequate longterm ground truth data.

The soil characteristics of the soil infiltration capacity of the Noah land surface model (LSM) corresponded to the soil water capacity. This information was estimated based on the MODIS soil classification. This consists of calculating the average of the capacities of all soil types in the watershed through weighting with their respective superficies.

\subsection{Atmospheric Model (Advanced Research WRF)}

The Advanced Research WRF (ARW) model (V3.5) [23] is used to perform the simulations over the study area. The initial attempt is to run a fully coupled WRF/WRF-Hydro model simulation for the climate projections since this approach was quite successful for present climate and hydrological studies [1]. This was to generate both future climate and hydrological simulated data for analysis. However, this attempt failed and the reasons for the failure could be attributed to model instability related to WRFHydro model deficiencies in handling radiative forcing data in a fully coupled approach and possibly computational challenges. As far as this study is concerned there is still no climate change studies carried out using WRF coupled with WRF-Hydro. What is available is using output from a standalone WRF-Hydro model. The simulation was therefore based on a standalone regional climate model (WRF) to generate future climate data. In this case, a one-way nested domain was set-up; the outer domain with a $25 \mathrm{~km}(160 \mathrm{x}$ 130 grid points) horizontal resolution, covering the West Africa region and the inner domain at $5 \mathrm{~km}(111 \mathrm{x} 111$ grid points) horizontal resolution, covering the Northern part of Ghana and the Southern part of Burkina Faso (Figure 3a). The inner domain was designed to better resolve the mesoscale features of the Tono basin located within this inner domain (Figure 3b). 


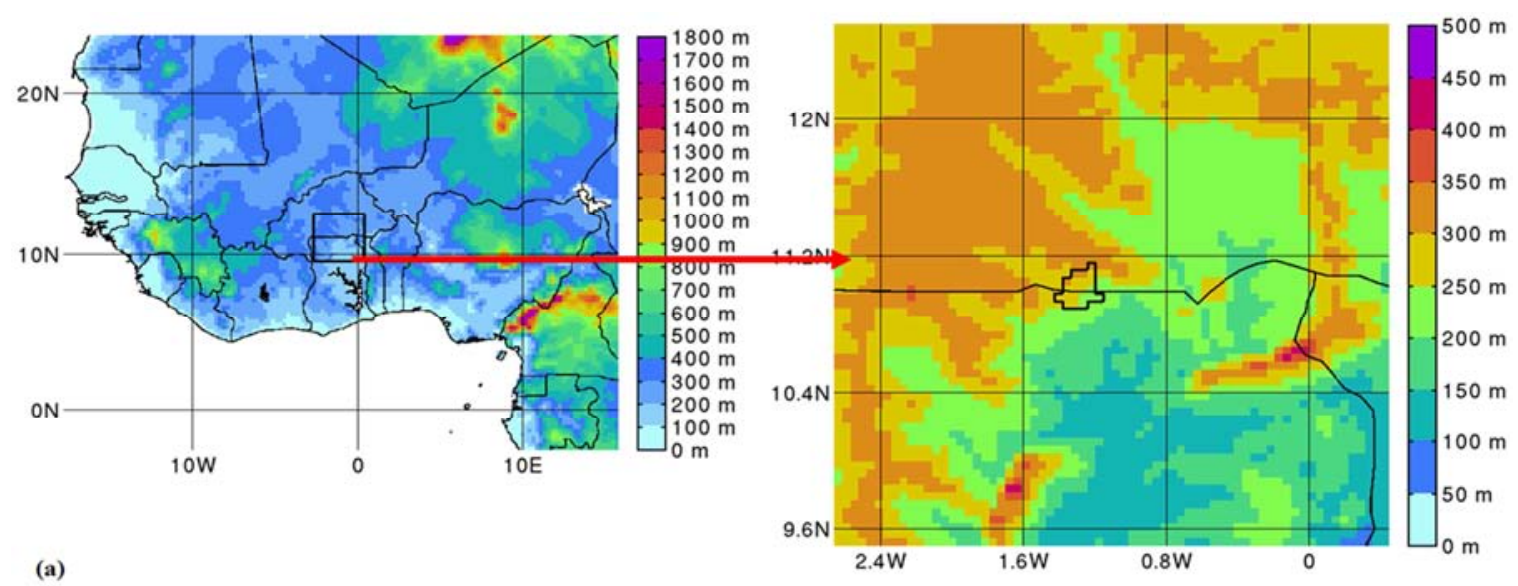

(b)

Figure 3. WRF outer domain at $25 \mathrm{~km}$ horizontal resolution (a), WRF inner domain at $5 \mathrm{~km}$ (b).

The vertical resolution in both domains is for thirty-five (35) vertical levels in the boundary layer with a model top at twenty (20) hPa. Studies carried out under the West African Science Service Center on Climate Change and Adapted Land Use (WASCAL) project [24] came out with optimal physical parameterizations for the West African Region. Their studies showed the physical parametrizations used, produced good replication of precipitation and temperature distributions over the West Africa Region at a horizontal resolution of $12 \mathrm{~km}$ for the period 1980-2010. In the current study, we used their physical parameterization options presented in Table 1, hence there was no need to carryout calibration of the model.

Table 1. WRF model physical options used.

\begin{tabular}{lll}
\hline Physics Categories & Selected Option & Reference \\
\hline Microphysics & Single Moment 5, WSM5 & {$[25]$} \\
Cumulus paramterisation & *Grell-Devenyi & {$[26]$} \\
Planetary boundary layer & ACM2 & {$[27]$} \\
Land surface model & Noah LSM & {$[28]$} \\
Longwave radiation & Rapid Radiative Transfer & {$[29]$} \\
& Model (RRTM) & {$[30]$} \\
\hline
\end{tabular}

*Only for the outer domain.

However, the cumulus scheme for the nested domain was switched off, considering the spatial resolution of the nested domain was in the convective permitting scale (between 3 and 5 $\mathrm{km}$ ) and would expect cumulus activities to be explicitly resolved at this scale. The Noah LSM was used in the WRF simulation. It accounts for the column hydrological processes (i.e. through fall, evapotranspiration, soil infiltration, vertical soil water movement and accumulation of both surface and underground runoff). The required input fields passed from the Noah LSM to the routing modules include maximum soil moisture for each soil type, infiltration capacity excess, lateral surface hydraulic conductivity for each soil type and the soil moisture content for each soil layer. Land cover and soil categories used in this study is the MODIS land surface data sets. The soil column configuration used in this study has the depth of the bottom of the layers as $0.05,0.25,0.70,1.50 \mathrm{~m}$. The choice of configuration set-up as indicated in many studies, especially over West Africa is quite subjective, based on the variable of interest, the focus of the region (study area), the verification methods and the chosen reference data sets [31, 32].

Studies on climate change impact depend on projections of future human activities. IPCC over the years continues to improve emission scenarios to be used in driving GCM to develop climate change scenarios. The kind used in this study is the Representative Concentration Pathways (RCPs), published in its Synthesis Report, 2014 which is more recent than the SRES scenarios. IPCC describes emission scenarios as an alternative image of the future socio-economic, demographic and technological change. Anthropogenic GHG emissions are driven mainly by the factors mentioned above (i.e. socio-economic, demographic characteristics and technological advancement). The RCPs, which are used for making projections, describe four different $21^{\text {st }}$ Century pathways of GHG emissions and atmospheric concentrations, air pollutant emissions and land use (IPCC, 2014). The RCPs include a stringent mitigation scenario (RCP2.6), two intermediate scenarios (RCP4.5 and RCP6.0) and one scenario with very high GHG emissions (RCP8.5).

The initial and lateral boundary conditions of the WRF model for this study were from ECHAM6, a T255 spectral resolution $(\sim 80 \mathrm{~km})$ [34]. The scenarios used were the Representative concentration pathways (RCPs) 4.5 and 8.5. The intention is to understand how each of these scenarios will influence future climate and its related impact on 
streamflow over the Tono basin.

\subsection{Climate Change Analysis}

We compared the annual simulated climate data from 2025 to 2045 according to RCPs 4.5 and 8.5 with observation values as a baseline (1990-2010). The simulated climate for 2025-2045 reproduced the characteristics (amount, intensity and distribution) of the observed data sets. This confirms similar studies [e.g. 35-38]. Their studies compared simulated RCPs with observation over West Africa, which indicated that, RCP8.5 gives a strong reflection of the observed data sets. The change in mean precipitation and temperature as the deviation of the projection from the reference period. These changes are expressed in an annual time series plot, relative percentage change and spatial maps of seasonal change. The relative percentage change was calculated according to the following formula:

$$
\Delta_{i}^{P s}=\frac{\left(\overline{X_{l}^{P S}}-\overline{X^{b a s}}\right)}{X^{\text {bas }}} \times 100
$$

Where $\Delta_{i}^{P s}$ is the relative percentage change calculated over the specified time period, $\overline{X^{b a s}}$ is the annual mean value calculated over the reference period, and $i$ is the time step. This rate of change represents the relative increase or decrease in annual and seasonal precipitation and temperature for the future.

\section{Results and Discussions}

To assess the sustainability of water resources in climate change context, it is necessary to model how these resources will behave in the future. Several studies have indicated that the future water availability will be affected not only by population increase but by a combination of climate change and the exponentially increasing demography [39]. Such changes are likely to have far-reaching consequences on every aspect of human well-being, agriculture and energy production, flood control and ecology of freshwater environments. Modelling the impact of climate change on water resources (e.g. dams, lakes, and rivers) will require long-term data including past and estimated future data sets [39]. Finding adequate long-term data in this region is a major challenge. This section presents the assessment of climate change and its consequent impact on water resources (particularly the Tono irrigation dam) that are mainly depended on for agriculture. It explores the projected changes in precipitation and temperature under RCP scenarios (developed by IPCC) and how these changes could influence future streamflow contribution into the dam for irrigation activities.

\subsection{Climate Change Analysis}

\subsubsection{Precipitation}

The average monthly precipitation with respect to the baseline (1990 to 2010) and projected period (Ps), 2025 to 2045, under RCPs 4.5 and 8.5 is presented in figure $4 \mathrm{a}$ and the relative percentage change in figure $4 \mathrm{~b}$. Both climate scenarios indicate an overall increase in average monthly precipitation compared to the referenced period. Additionally, though both scenarios show the same trend with respect to the reference period, RCP8.5 shows an earlier peak and also a lower precipitation amount at the peak of the rainy season compared to RCP4.5 (see figure 4a). From April to the peak of the rainy season (August), both scenarios generally indicate an increasing rainfall amount (figure 4b). However, under RCP4.5, there is a higher percentage increase of rainfall ranging from $10 \%$ to $25 \%$ compared to RCP 8.5 with a change of $5 \%$ to $15 \%$. Toward the end of the rainy season (September-October), both scenarios indicate a percentage decrease in precipitation. Between November and December, RCP4.5 indicates a precipitation percentage change of $80 \%$ and $100 \%$ respectively, but RCP 8.5 rather indicates a $25 \%$ decrease in rainfall. Generally, rainfall amounts within this period are relatively less than $4 \mathrm{~mm}$ /day or in most cases rainfall does not occur. Therefore the higher percentage change in rainfall indicated by RCP4.5 will not generate significant flows to contribute to the dam level.

Table 2. Projected changes of temperature and rainfall in the Tono basin under RCPS 4.5 and 8.5.

\begin{tabular}{lllll}
\hline Baseline (1990-2010) & \multicolumn{5}{l}{} & & \\
\hline Average & Change & $\mathbf{2 0 2 5 - 2 0 4 5}$ & \\
\hline Temperature & $27.2 \mathrm{C}$ & RCP4.5 & $28.5 \mathrm{C}$ & $+5 \%$ \\
RCP8.5 & & & $28.8 \mathrm{C}$ & $+6 \%$ \\
Rainfall & \multirow{2}{*}{ RCP4.5 } & $924.5 \mathrm{~mm}$ & $+8 \%$ & $-9 \%$ \\
& & RCP 8.5 & $781.9 \mathrm{~mm}$ & \\
\hline
\end{tabular}

Table 2 shows an increase $(+8 \%)$ in annual mean rainfall under RCP4.5 scenario and a decrease in annual mean rainfall under RCP8.5 in the basin. The decrease in annual mean rainfall under RCP8.5 is pronounced and therefore will lead to worst situation in respect lower streamflow compared to the baseline with a reduction of $-9 \%$ for the projected period. This implies that, the scenarios do not agree on the signal of precipitation change. The annual mean rainfall for the baseline period is $856.7 \mathrm{~mm}$, whiles RCP4.5 is $924.5 \mathrm{~mm}$ and RCP8.5 is $781.9 \mathrm{~mm}$ for the projected period. The rainfall deficit and characteristics exhibited under RCP8.5 has already been observed by many authors in West Africa [2, 40-42].

The IPCC climate projections assessment in 2007 indicated increases in precipitation amounts are very likely in the high latitudes and decreases are likely in the subtropical land regions by as much as $20 \%$ in the A1B scenario in 2100 . However, the climate models fail to agree on the sign of the 
future evolution of precipitation over West Africa as indicated in this study. About $50 \%$ of these models project an increase in rainfall whereas the other $50 \%$ project a decrease $[43,36]$. These changes were suggested to range between -20 to $20 \%$ in annual rainfall [44].

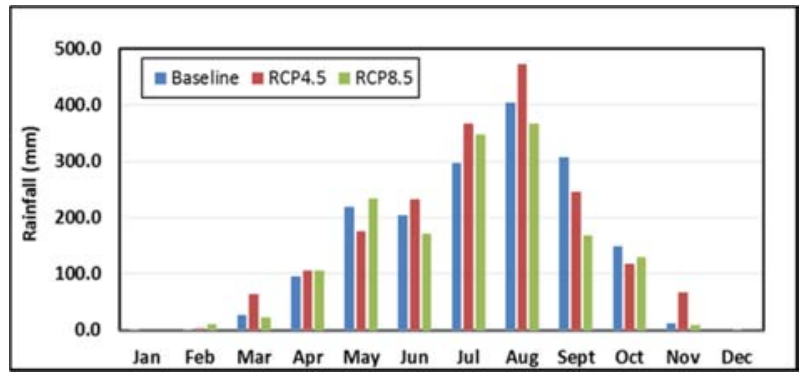

(a)

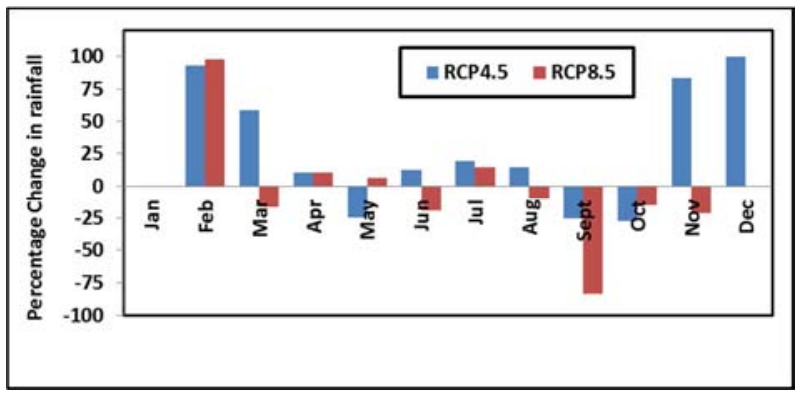

(b)

Figure 4. Projected change in monthly inter-annual mean rainfall (a) and percentage change in rainfall (b).
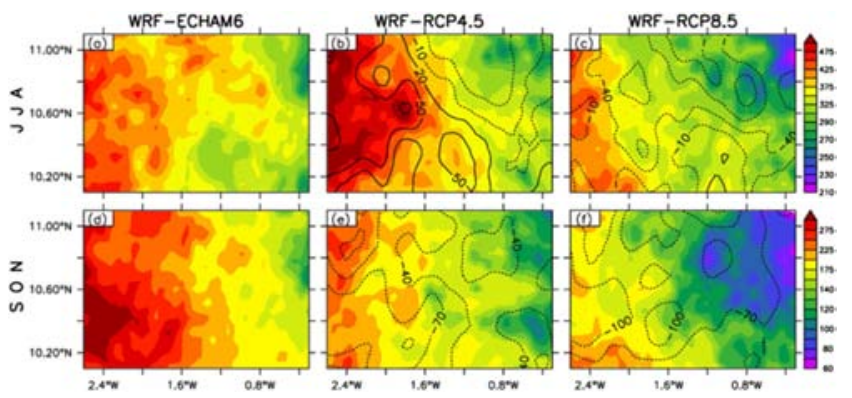

Figure 5. (a) to (c) JJA and (d) to (f) SON seasonal precipitation change (bias) maps. Precipitation for controlled period (ECHAM6, 1990-2010) and Precipitation for projected period (RCP4.5 and RCP8.5, 2025-2045) over the Tono Basin.

Figure 5 presents the seasonal variations of the precipitation change of the two scenarios with respect to the controlled period. The seasonal rainfall at the Tono basin occurs in June, July, August (JJA), peaks in August and September, and then drops in October, November (SON). Both scenarios capture the position of intense rainfall (towards the west) (figure 5). RCP4.5, for JJA season, indicates a precipitation change ranging from +20 to $+50 \mathrm{~mm}$, whereas RCP8.5 indicates a decrease in precipitation change of -10 to $-40 \mathrm{~mm}$ as reflected on the monthly rainfall analysis. However, both scenarios for SON season indicate a decreasing precipitation change; with RCP8.5 showing higher decreasing values (see also figure 5).
RCP4.5 presents a case of intense rainfall and shorter duration which reflects in the studies by [37]. They described the changes in the rainy season over West Africa as one of a delayed onset and early cessation, thus shortening the rainy season. This is even worse when we consider RCP8.5 scenario which projects a decrease in rainfall amounts. The seasonal trend and magnitude of change as indicated in figure 6 reflects the above analysis. DJF and MAM season are dry season (no rainfall) periods, however, RCP8.5 projects an increase in rainfall more than RCP4.5. For the rainfall season JJA and SON, RCP4.5 projects an increase in rainfall more than RCP8.5 with a magnitude of change more than 0.2 $\mathrm{mm} /$ day.

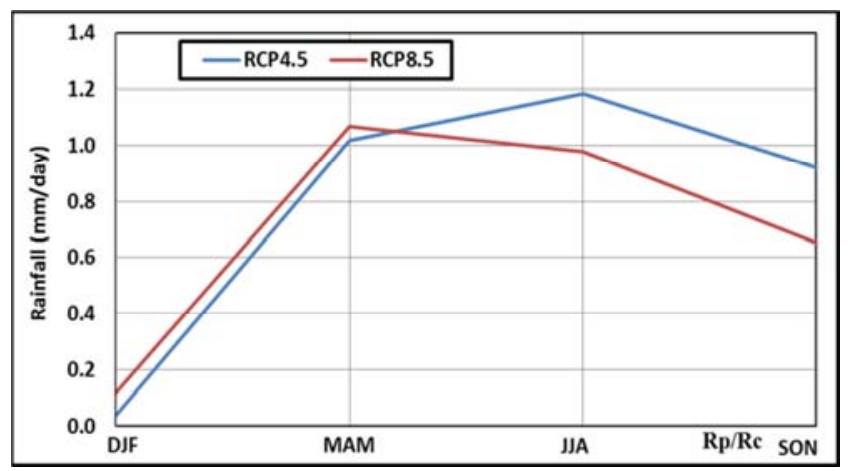

Figure 6. Projected seasonal rainfall trend and the magnitude of change of rainfall under RCP4.5 and RCP8.5.

However, it is important to note that both scenarios project the precipitation patterns of the baseline period. The sign or magnitude of change is quite different depending on the season.

\subsubsection{Temperature}

Figure 7 presents the baseline period (1990 to 2010) and the projected period (2025 to 2045) inter-annual monthly mean temperatures of the Tono basin under the RCP4.5 and 8.5 scenarios. Compared to the baseline, both scenarios project an increasing temperature with RCP 8.5 been more pronounced, however, RCP4.5 indicates a higher percentage change in temperature for January and February (figure $7 b$ ). RCP8.5 is seen as the most pessimistic scenario [2, 45]. Apart from January and February, the highest temperatures were seen under RCP8.5. Therefore the mean temperature over the basin for the hottest month (April) is $32.6^{\circ} \mathrm{C}$ and $24.8^{\circ} \mathrm{C}$ in January (coolest month due to the harmattan winds).

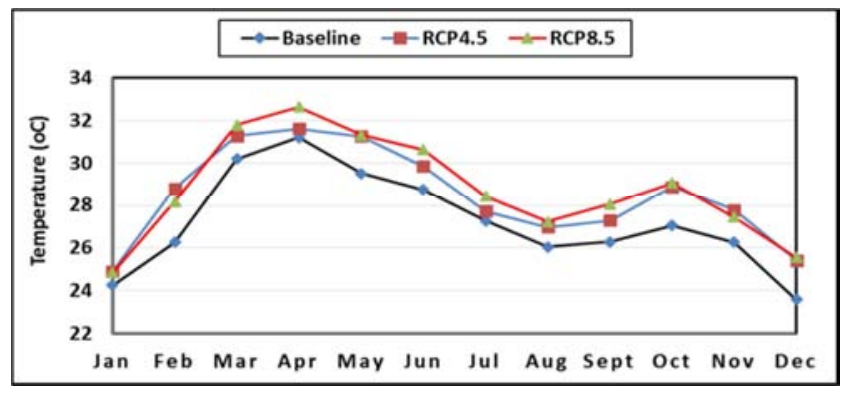

(a) 


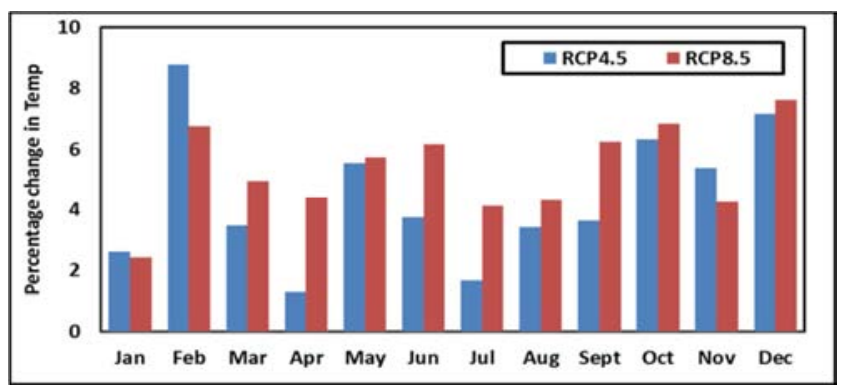

(b)

Figure 7. Projected monthly inter-annual cycle of temperature (a) and Percentage change in temperature under RCP4.5 and RCP8.5 (b).

For RCP4.5, the temperatures will be $31.7^{\circ} \mathrm{C}$ and $24.9^{\circ} \mathrm{C}$ for the months of March and January, respectively. The increase in temperature by both scenarios reflects the rate at which temperature is increasing over West Africa as indicated in many studies [2, 40-42, 45].

The projected annual mean temperatures under RCP4.5 and RCP8.5 indicates a rising temperature as mentioned earlier when compared to the baseline (1990-2010) in the Tono basin (see table 2). RCP8.5 indicates the highest temperature change of $6 \%\left(+1.6^{\circ} \mathrm{C}\right)$ for the projected period whereas $\mathrm{RCP} 4.5$ indicates a temperature change of $5 \%\left(1.3^{\circ} \mathrm{C}\right)$. The temperature variations obtained from this study are close to the results of Coulibaly et al., 2018 where he obtained a temperature increasing 5.9\% for climate period (2021-2040) under RCP8.5 [2]. These projections are also within the range $\left(+0.6^{\circ} \mathrm{C}\right.$ to $+4.0^{\circ} \mathrm{C}$ ) of Sylla, 2015, Christensen et al., 2007, IPCC, 2007 $[35,38,46]$. The Projections all agree on a warming in WA even though the magnitude varies across climate models.

In addition the variations in the temperature change (low and high) as indicated in figure $7 \mathrm{~b}$ are close to the conclusions of Sylla, 2015 for the West Africa region, which suggested that temperature changes are substantially larger in RCP8.5 with an increase of between $4^{\circ} \mathrm{C}$ and $7^{\circ} \mathrm{C}$ compared with the RCP4.5 under which an increase of between $1^{\circ} \mathrm{C}$ and $3^{\circ} \mathrm{C}$ is seen [35].

The seasonal change in temperature as presented in figure 8 shows that both RCP4.5 and 8.5 as having increases in temperature change. However, as expected the RCP4.5 shows a lower rate of change in temperature between $+0.4^{\circ} \mathrm{C}$ to $+1.6^{\circ} \mathrm{C}$ compared to $\mathrm{RCP} 8.5\left(+0.8^{\circ} \mathrm{C}\right.$ to $\left.+2.2^{\circ} \mathrm{C}\right)$ over the Tono basin.
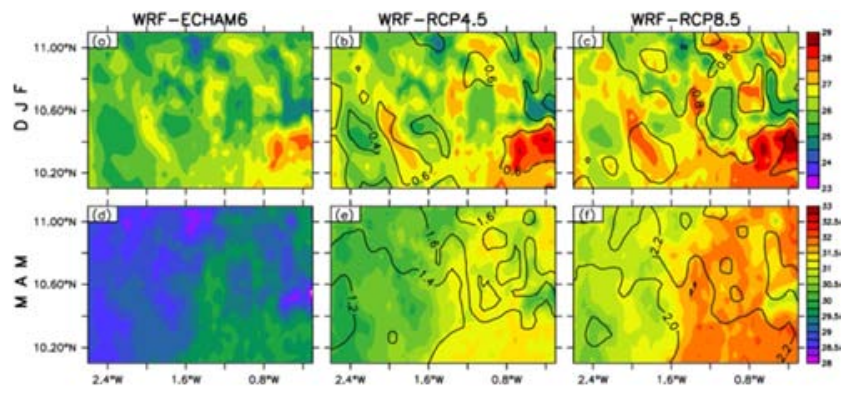

Figure 8. (a) to (c) DJF and (d) to (f) MAM seasonal temperature change (bias) maps. Temperature for controlled period (ECHAM6, 1990-2010) and Temperature for projected period (RCP4.5 and RCP8.5, 2025-2045).

These results reflect that of the annual mean temperature change. The seasonal trend and magnitude of change as presented in figure 9 also confirms both scenarios as having increasing temperature compared to the baseline, however, RCP8.5 scenario projects a more pronounced change. Particularly for the dry season (MAM) and the rainy season (JJA), RCP8.5 records the highest magnitude of temperature change with $0.5^{\circ} \mathrm{C}$ and $0.6^{\circ} \mathrm{C}$ respectively (figure $9 \mathrm{~b}$ ). This characteristics has greater influence on streamflow amounts and dam levels.

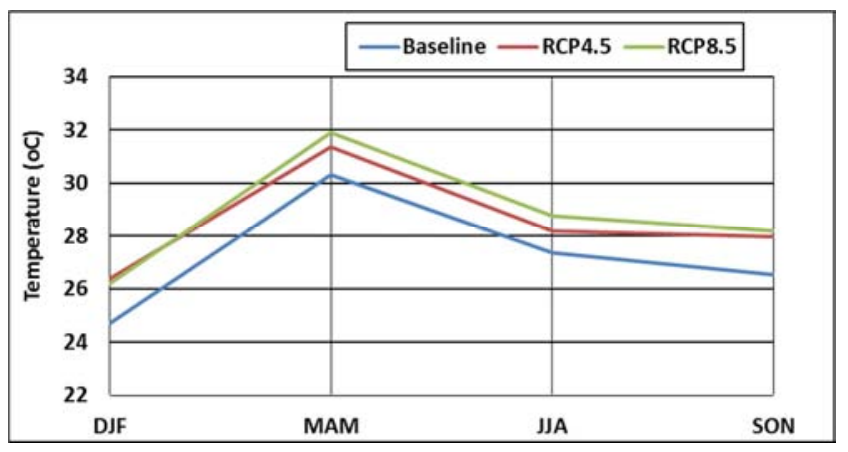

(a)

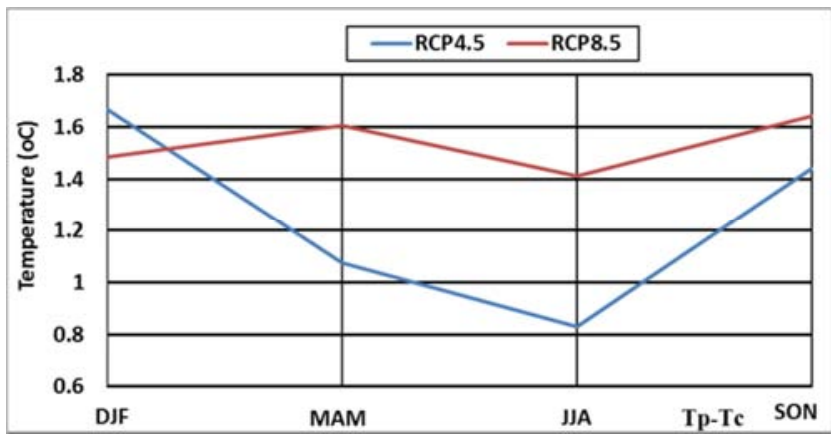

(b)

Figure 9. Projected seasonal temperature trend (a) and the magnitude of change of temperature under RCP4.5 and RCP8.5 (b).

The climate projections on precipitation and temperature analysis reflects many of the studies carried out in West Africa [e.g. 2, 41, 45] which indicates that anthropogenic climate change will significantly influence extreme precipitation and temperature events and lead to shifts in the different moisture zones.

\subsection{Climate Change Impact on Streamflow}

Several studies have shown that discharge evolutions over the past decades in West Africa (WA) have been strongly affected by rainfall variations. For example after the wet 1950 s and 1960s, a strong rainfall deficit has been happening since 1970 in the Sahelian and Sudan-Sahelian regions [47] with dramatic droughts like the 1973/1974 and 1983/1984 cases [48]. IPCC, 2007 indicated a recovery of the rainfall in eastern parts of WA for the period 1990-2007, whereas drought conditions continue to prevail in the western parts [49]. These rainfall variations have led to strong fluctuations in river discharge with a general negative trend from 1960 to 2010 [50], mostly in Sudanian parts. Though it is also the 
case in Gulf of Guinea areas, the decrease is quite moderate. The non-linear effect of this rainfall drop over much of WA underlined by Mahe et al., 2013 indicates a $20 \%$ decrease in rainfall resulting in a decrease of $60 \%$ in the runoff [51].

The characteristics of WA climate and climate projections carried out by previous studies [2, 35, 14, 15] have been confirmed in this current study over the Tono basin. Both scenarios present a potential threat to the future of the hydrological cycle of the Tono basin. A decrease in rainfall and increasing temperature will have negative impact on the availability of surface and sub-surface water. The magnitude or percentage change in future stream flows remains uncertain over WA. This uncertainty stems from the fact that, precipitation projections are quite uncertain and most of the scenarios do not agree on the direction of change. Some studies have suggested that for a predicted reduction in rainfall of 10 to $20 \%$, a fall-off in flow of 20 to $40 \%$ might be expected [52] over WA. However, this could vary from one basin to the other depending on the runoff-precipitation ratio of that basin.

High rainfall intensity as indicated under RCP4.5 will result in increase in surface runoff, thus increasing the volume of water in the Tono dam. However, because the duration of rainfall intensity is short coupled with increases in temperature during this period, the increase in dam level will not be significant but might experience stable level. RCP8.5 scenario projects decreasing precipitation change and an increasing temperature change. The signal of change in precipitation and temperature reflects the climate pattern of the baseline period. The indications are that, this scenario could lead to less surface runoff and high evaporation rate and therefore decreasing dam level. Without control this projection could lead to the possibility of the Tono dam going dry.

\section{Conclusions}

This study used the Weather Research and Forecasting (WRF) model as a regional climate model (RCM) to assess the potential impact of climate change on the Tono dam. The climate assessment and its potential impact on water resources was based on the future climate projected for the period, 2025-2045 under the scenarios RCP4.5 and RCP8.5.

$\mathrm{RCP} 4.5$ reflects an increasing rainfall intensity and a shorter duration with increasing temperature. This will lead to water resources filling up during the rainy season but water levels immediately reduces due to increasing evaporation as a result of high temperature low relative humidity. RCP8.5 presents a worse climate situation, with a decreasing rainfall and an increasing temperature change. This implies less flows into the water resources and the available water in the reservoirs decreasing rapidly (going dry) due to increasing evaporation rate.

Both scenarios do not agree on the signal of change with respect to precipitation, however, with respect to temperature both scenarios indicate warmer conditions.

It is expected that future population of WA would increase significantly, with increased industrial activities, increased technology, and increased commercial agriculture. All these if not checked with sustainable measures will lead to increase greenhouse gas emissions (GHG) thus placing the region under climate scenario RCP8.5. The implications of this scenario over the basin include but not limited to; a decrease in annual river flows reflecting the drop in rainfall and a depletion of surface water resources. Other implications are, a drastic fall in water volumes transiting through the major rivers, an increase in runoff coefficient for the small basins and a failure to fill the dam reservoir during the rainy season. In addition, it will also lead to an intensification of the hydrological cycle, an increase in the scale or frequency of flooding, more and more severe droughts and deterioration in water quality.

The possibility of running a coupled atmospheric, hydrological model for future climate projections based on the Representative Concentration Pathways (RCPs) need to be explored so as to improve on the climate and hydrological results for improved assessment on the impact of climate change on the water resources of West Africa.

\section{Acknowledgements}

We are indeed grateful to the German Federal Ministry of Education and Research (BMBF) through the West African Science Service Center on Climate Change and Adapted Land Use (WASCAL) for providing Naabil Edward the research fund. We also acknowledge University of Leeds Cheney Fellowship and the UK Research and Innovation as part of the Global Challenges Research Fund (GCRF African SWIFT) for providing funding for the publication of this paper. We would like to thank the German Climate Computing Center (DKRZ) for providing the computing facilities. We acknowledge the Max-Planck-Institut für Meteorologie for providing the ECHAM6 model data, the NASA GSFC/DAAC for the TRMM products.

\section{References}

[1] Naabil, E., Lamptey, B. L., Arnault, J., Olufayo, A., Kunstmann, H., 2017: Water resources management using the WRF-Hydro modeling system: Case-study of the Tono dam in West Africa. Journal of Hydrology: Regional Studies 12, 196-209.

[2] Coulibaly, N., Coulibaly, T. J. H., Mpakama, Z., Savané, I., 2018: The Impact of Climate Change on Water Resource Availability in a Trans-Boundary Basin in West Africa: The Case of Sassandra. Hydrology, 5, 12; doi: 10.3390/hydrology5010012.

[3] Abdelkrim, B. S., 2013: Vulnérabilité et Adaptation Aux Changements Climatiques Dans les Oasis de la Région de Tafilalet-Maroc. Ph. D. Thesis, Université Cadi Ayyad, Marrakesh, Maroc.

[4] Kouassi, A. M.; Kouamé, K. F.; Saley, M. B.; Biémi, J., 2013: Application du modèle de maillet à l'étude des impacts des changements climatiques sur les ressources en eau en Afrique de l'Ouest: Cas du bassin versant du N' Zi-Bandama (Cote d'Ivoire). IJSRM, 3, 214-228. 
[5] Goula, B. T. A.; Savane, I.; Konan, B.; Fadika, V.; Kouadio, G B., 2007: Impact de la variabilité climatique sur les ressources hydriques des bassins de N'Zo et N'Zi en Côte d'Ivoire (Afrique tropicale humide). Vertigo, 7.

[6] Kouakou, K. E.; Goula, B. T. A.; Savané, I., 2007: Impacts de la variabilité climatique sur les ressources en eau de surface en zone tropicale humide: Cas du bassin versant transfrontalier de la Comoé (Côte d'Ivoire-Burkina Faso). EJSR, 16, 31-43.

[7] Vissin, E. W., 2007: Impact de la Variabilité Climatique et de la Dynamique Des États de Surface Sur Les Écoulements du Bassin Béninois du Fleuve Niger. Ph. D. Thesis, Université de Bourgone, Dijon, France.

[8] Kouakou, K. E., 2011: Impacts de la Variabilité Climatique et du Changement Climatique Sur Les Ressources eneau en Afrique de l'Ouest: Cas du Bassin Versant de la Comoé. Ph. D. Thesis, Université Abobo-Adjamé, Abidjan, Côte d'Ivoire.

[9] Ardoin, B. S., 2004: Variabilité Hydroclimatique et Impacts Sur Les Ressources en Eau de Grands Bassins Hydrographiques en Zone Soudano-Sahélienne. Ph. D. Thesis, Université de Montpellier II, Montpellier, France.

[10] Melillo, Jerry M., Terese (T. C) Richmond, and Gary W. Yohe, Eds., 2014: Climate Change Impacts in the United States: The Third National Climate Assessment. U.S. Global Change Research Program, 841 pp.

[11] Arnault, J., Wagner, S., Rummler, T., Fersch, B., Blieffernicht, J., Andresen, S., Kunstmann, H., 2015: Role of runoffinfiltration partitioning and additionally resolved overland flow on land-atmosphere feedbacks: A case study with the WRFHydro coupled modeling system for West Africa. Journal of Hydrometeorology. Doi: http://dx.doi.org/10.1175/JHM-D-150089.1.

[12] Ardoin, B. S.; Dezetter, A.; Servat, E.; Mahe, G.; Paturel, J. E.; Dieulin, C.; Casenave, L., 2005: Évaluation des impacts du changement climatique sur les ressources en eau d'Afrique de l'Ouest et Centrale. Proceedings of symposium S6 held during the Seventh IAHS Scientific Assembly at Foz do Iguaçu, Brazil. IAHS Publ. 296, 194-202.

[13] Rescan, M., 2005: Prévision des Ressources en eau en Afrique de L'ouest et Centrale Jusqu'en 2099 Par Application Des Sorties du Modèle D'évolution du Climat HadCM3 au Modèle Hydrologique GR2M; DEA; Université Montpellier II: Montpellier, France.

[14] Yao, A. B. 2015: Evaluation Des Potentialités en Eau du Bassin Versant de la Lobo en Vue D'une Gestion Rationnelle (Centre-ouest de la Côte d'Ivoire). Ph. D. Thesis, Université Nangui Abrogoua, Abidjan, Côte d'Ivoire.

[15] Abiodun, B. J.; Lawal, K. A.; Salami, A. T.; Abatan, A. A., 2013: Potential influences of global warming on future climate and extreme events in Nigeria. Reg. Environ. Chang. $13,477-491$.

[16] Sylla M. B, Gaye, A. T., Jenkkins, G. S., Pal, J. S., and Giorgi, F., 2010: Consistency of projected drought over the Sahel with changes in the monsoon circulation and extremes in a regional climate model projections. Journal of Geophysical Research, VOL. 115, D16108, doi: 1029/2009JD012983.

[17] Barthony, J., Pongracz, R., Kovacs, G., Torma, C., 2010: Analysis of Regcm Simulations using A1B emission Scenario: estimated mean and extreme climate trends in the Carpathian basin. Vol. 12, EGU2010-13624.
[18] Mariotti, Laurh \& Sylla, Mouhamdou \& Coppola, Erika \& A. Rauscher, S \& Piani, Claudio \& Giorgi, F., 2008: Dynamical Downscaling of climate change Projection over the African Region using the Regional Climate Model (Regcm3). AGU Fall Meeting Abstracts.

[19] Huffman, G. J., R. F. Adler, D. T. Bolvin, G. Gu, E. J. Nelkin, K. P. Bowman, Y. Hong, E. F. Stocker, D. B Wolff, 2007: The TRMM Multi-satellite Precipitation Analysis: QuasiGlobal, Multi-Year, Combined-Sensor Precipitation Estimates at Fine Scale. J. Hydrometeor., 8: 38-55.

[20] Mitchell, T. D., Jones, P. D., 2005: An improved method of constructing a database of monthly climate observations and associated high resolution grids. Int. J. Climatol. 25: 693-712.

[21] Sibson, R., 1981: A brief description of natural neighbor interpolation, in interpreting multivariate data, edited by Barnett, pp. 21-36, John Wiley and Sons, Chichester, UK.

[22] Hofstra N., Haylock, M., Mark N., Phil J., Christoph F., 2008: Comparison of six methods for the interpolation of daily European climate data. Journal of Geophysical research, Vol. 113.

[23] Skamarock W, Klemp J. B, Dudhia J, Gill D, Barker D, Duda M, Huang X, Wang W, Powers J., 2008: A description of the advanced research WRF version 3. NCAR Technical Note, NCAR/TN-475 + http://www.mmm.ucar.edu/wrf/users/docs/arw_v3.pdf. Accessed 17 September 2014.

[24] Heinzeller, D., Klein, C., Deing, D., Smiatek, G., Bliefernicht, J., 2015: The WASCAL regional climate simulations for West Africa: How to add value to existing climate projections. https://www.dkrz.de/mms/pdf/workshop_2015/poster_0726.p df.

[25] Hong, S.-Y., Dudhia, J. and Chen, S.-H., 2004: A Revised Approach to Ice Microphysical Processes for the Bulk Parameterization of Clouds and Precipitation. Monthly Weather Review, 132, 103-120.

[26] Grell and Devenyi, 2002: GRL, in ARW, Version 3, Modeling System User's Guide, January, 2015.

[27] Jonathan E. Pleim, 2007: A Combined Local and Nonlocal Closure Model for the Atmospheric Boundary Layer. Part I: Model Description and Testing. J. Appl. Meteor. Climatol. 46 (9): 1383-1395

[28] Fei Chen and Jimy Dudhia, 2001: Coupling an Advanced Land Surface-Hydrology Model with the Penn State-NCAR MM5 Modeling System. Part I: Model Implementation and Sensitivity. Monthly Weather Review, 129, 569-585.

[29] Eli J. Mlawer, Steven J. Taubman, Patrick D. Brown, Michael J. Iacono, Shepard A. Clough, 1997: Radiative transfer for inhomogeneous atmosphere: RRTM, a validated correlated-k model for the longwave. Journal of Geophysical Research: Atmospheres. Vol. 102, Issue D14.

[30] Dudhia J., 1989: Numerical study of convection observed during the winter monsoon experiment using a mesoscale twodimensional model. J Atmos Sci 46: 3077-3107.

[31] Klein, C., Heinzeller, D., Bliefermicht, J., Kunstmann, H., 2015: Variability of West Africa Monsoon patterns generated by a WRF multi-physics ensemble. ClimDyn. doi $10.1007 / s 00382-015-2505-5$. 
[32] Sylla M. B, Diallo I, Pal J. S, 2013: West African monsoon in state of-the-science regional climate models, climate variability-regional and thematic Patterns. Dr. AondoverTarhule (Ed.), ISBN: 978-953-51-1187-0, InTech, doi: $10.5772 / 55140$.

[33] IPCC, 2014: Climate Change 2007: Synthesis Report. Contribution of Working Groups I, II and III to the Fifth Assessment Report of the Intergovernmental Panel on Climate Change [Core Writing Team, R. K Pachauri and L. A. Meyer (eds.)]. IPCC, Geneva, Switzerland, $151 \mathrm{pp}$.

[34] Berrisford, P., Kallberg, P., Kobayashi, S., Dee, D., Uppala, S. Simmons, A. J., Poli, P., and Sato, H., 2011: Atmospheric conservation properties in ERA-Interim, Q. J. Roy. Meteorol. Soc., 137, 1381-1399, doi: 10.1002/Qj.864.

[35] Sylla, M. B., 2015: Development and Analysis of Climatological Baseline and Climate Change Scenarios for Ecowas. Technical Report for United Nations University Institute for Natural Resources in Africa (UNU-INRA) Project: Climate Change, Agricultural Trade and Food Security in ECOWAS; United Nations University: Tokyo, Japan.

[36] Berg, A., de Noblet-Ducoudré, N., Sultan, B., Lengaigne, M., and Guimberteau, M., 2013: Projections of climate change impacts on potential $\mathrm{C} 4$ crop productivity over tropical regions, Agr. Forest Meteorol., 170, 89-102, doi: 10.1016/j.agrformet.2011.12.003.

[37] Biasutti, M. and Sobel, A. H., 2009: Delayed Sahel rainfall and global seasonal cycle in a warmer climate, Geophys. Res. Lett., 36, L23707, doi: 10.1029/2009g1041303.

[38] Christensen, J. H., Hewitson, B., Busuioc, A., Chen, A., Gao, X., 2007: Regional Climate Projections, in: Climate Change 2007: The Physical Science Basis, Contribution of Working Group I to the Fourth Assessment Report of the Intergovernmental Panel on Climate Change, edited by: Solomon, S., Qin, D., Manning, M., Chen, Z., Marquis, M., Averyt, K. B., Tignor, M., and Miller, H. L., Cambridge University Press, Cambridge, UK and New York, NY, USA.

[39] Kumambala, P. G., 2010: Sustainability of water resources development for Malawi with particular emphasis on North and Central Malawi. PhD thesis. http://theses.gla.ac.uk/1801/.

[40] Soro, G. E.; Yao, A. B.; Kouame, Y. M.; Goula Bi, T. A., 2017: Climate Change and its Impacts on Water Resources in the Bandama Basin, Cote d'Ivoire. Hydrology, 4, 18.

[41] Sylla, M. B.; Nikiema, P. M.; Gibba, P.; Kebe, I.; Klutse, N. A. B., 2016: Climate Change over West Africa: Recent Trends and Future Projections. In Adaptation to Climate Change and Variability in Rural West Africa; Yaro, A. J., Hesselberg, J., Eds.; Springer International Publishing: Cham, Switzerland, pp. 25-40.

[42] Mbaye, M. L.; Hagemann, S.; Haensler, A.; Stacke, T.; Gaye, A. T.; Afouda, A., 2015: Assessment of Climate Change
Impact on Water Resources in the Upper Senegal Basin (West Africa). Am. J. Clim. Chang. 4, 77-93.

[43] Vigaud, N., Roucou, P., Fontaine, B., Sijikumar, S., and Tyteca, S., 2011: WRF/ARPEGE-CLIMAT simulated climate trends over West Africa, Clim. Dynam., 36, 925-944, doi: $10.1007 / \mathrm{s} 00382-0090707-4$

[44] Sultan, B., Roudier, P., Quirion, P., Alhassane, A., Muller, B., 2013: Assessing climate change impacts on sorghum and millet yields in the Sudanian and Sahelian savannas of West Africa, Environ. Res. Lett., 8, 014040, doi: 10.1088/17489326/8/1/014040.

[45] IPCC, 2013. Climate Change 2013: The Physical Science Basis. Contribution of Working Group I to the Fifth Assessment Report of the Intergovernmental Panel on Climate Change [Stocker, T. F., D. Qin, G.-K. Platner, M. Tignor, S. K Allen, J. Boschung, A. Nauels, Y. Xia, V. Bex and P. M. Midgley (eds.)]. Cambridge Uinersity Press, Cambridge, United Kingdom and New York, NY, USA, 1535 pp.

[46] IPCC, 2007: Climate Change 2007: Synthesis Report. Contribution of Working Groups I, II and III to the Fourth Assessment Report of the Intergovernmental Panel on Climate Change [Core Writing Team, Pachauri, R. K and Reisinger, A.(eds.)]. IPCC, Geneva, Switzerland, 104 pp.

[47] Paturel, J. E., Ouedraogo, M., Servat, E., Mahe, G., Dezetter, A., and Boyer, J. F., 2003: The concept of rainfall and streamflow normals in West and Central Africa in a context of climatic variability, Hydrolog. Sci. J., 48, 125-138.

[48] Roudier, P.; Ducharne, A.; Feyen, L., 2014: Climate change impacts on runoff in West Africa: A review. Hydrol. Earth Syst. Sci., 18, 2789-2801.

[49] Lebel, T. and Ali, A., 2009: Recent trends in the Central and Western Sahel rainfall regime (1990-2007), J. Hydrol., 375, 52-64, doi: 10.1016/j.jhydrol.2008.11.030.

[50] Descroix, L., Moussa, I. B., Genthon, P., Sighomnou, D., Mahé, G., 2013: Impact of Drought and Land - Use Changes on Surface - Water Quality and Quantity: The Sahelian Paradox, Curr. Perspect. Contam. Hydrol. Water Res. Sustain., in: Current Perspectives in Contaminant Hydrology and Water Resources Sustainability, chap. 10, edited by: Bradley, P. M., 243-271, doi: 10.5772/54536.

[51] Mahe, G., Lienou, G., Descroix, L., Bamba, F., Paturel, J. E., 2013: The rivers of Africa: witness of climate change and human impact on the environment, Hydrol. Process. 27, 21052114, doi: 10.1002/hyp.9813.

[52] Amani, A., Thomas, J., Mamouda, M. N. A., Afouda, A., Ndiaye, T., 2007: Climate Change Adaptation and Water Resources Management in West Africa. Syntheis ReportWRITESHOP. 